\title{
Macrothink
}

\section{The impact of the delegation of authority on employees' performance at great Irbid municipality: case study}

\author{
Hamdan Rasheed Al-Jammal \\ Associate Professor, Department of Financial \& Administrative Sciences \\ AL-Huson University College, AL-Balqa' Applied University, Irbid, Jordan \\ Akif Lutfi Al-Khasawneh (corresponding author) \\ Associate Professor, Department of Financial \& Administrative Sciences, \\ AL-Huson University College, AL-Balqa' Applied University, Irbid, Jordan, P. O. Box 50, \\ AL-Huson, 21510, Jordan \\ Email: akif_khasawneh@yahoo.com \\ Mohammad Hasan Hamadat \\ Assistant Professor, Ajloun University College \\ AL-Balqa' Applied University, Ajloun, Jordan, P. O. Box 33, Ajloun, Jordan
}

Doi:10.5296/ijhrs.v5i3.8062 URL: http://dx.doi.org/10.5296/ijhrs.v5i3.8062

\begin{abstract}
The study aimed at identifying the impact of the delegation of authority on employees' performance at great Irbid municipality. It has constructed on measuring the impact of delegation on efficiency, effectiveness and empowerment. Sample of the study represented by employees in which they are embedded in central and executive management through a random sampling reached to (200) employees from total (1500). The sample was used as a tool for achieving the results. After applying Alpha measurement, it has been shown that validity was $(82 \%)$. Means, standard deviation, percentages, (T-test), and Cronbach Alpha test were used and applied.

The results of the study have shown that there is a statically significant for delegation of authority on efficiency, effectiveness and empowerment of employees' performance at great Irbid municipality.

The study has recommended in the need to activating administrative delegation authority of employees in Great Irbid Municipality (GIM). Also, increase the level of delegation to be
\end{abstract}


corresponded with the value of tasks in order to promote functional performance. Moreover, improving administrative delegation of authority in which effect on employees' satisfaction, employees' empowerment to implement tasks individually without asking high management. This method will save time and effort. It will also offer service for customers rapidly and directly.

Keywords: delegation of authority, employees' performance, effectiveness of employee' performance, efficiency of employees' performance, empowerment of employees' performance.

\section{Introduction}

Delegation of authority is one of modern trends practiced by managers. It is function stands out contributing and increasing the level of motivation of employees and achieving positive returns for (an organization with a manager) and (an employee with a customer) both. On the level of an organization, it achieves competitive advantage, knowledge inventory, increases the level of productivity and speed in finalizing tasks effectively. On the level of manager, it alleviates functional burdens, gains employees' satisfaction and builds cooperation and trust between manger and employees giving a chance for manger to have full-time for realization more important work. So, it reduces physical and intellectual efforts exerted by manager and other employees. On the level of an employee, it works on achieving functional empowerment, constructing alternative and administrative leadership, making employees feel self-confidence and motivation for Excellency in performance. On the level of customer, it meets the needs of customers rapidly, delivering or providing the service will not be delayed due to delegation authority. Giving the customer a higher level of care and attention, building customer's perceived and creating loyalty and mutual respect for an organization and production in which the organization produced.

It can be said that method of delegation authority becomes inevitable issue for every organization whether in public or private sector. It is not optional due to many reasons has connected and brought developments and changes to the organizations including that (increasing its size and diversity of its products, multiplicity of its products and spread of its branches in different geographical zones and different local, regional and international levels. Managers have been imposed for the necessity to have a way for helping them in facilitating business affairs and alleviating the burdens in which they aren't tolerated, implemented and controlled by a manger. From other hand, different social and environmental transformations at organization have been changed since of classical school that was differentiated by centralism and subjecting to orders of mangers without reluctance. Implementing processes and procedures become more flexible, and free due to employees. The results of applying this principle has helped employees to be enhanced, imposed different functional rights for them, and necessity to transform from dictatorship to democracy associates with modern trends of management and employees' desires and wishes. In addition, managers will be able to maintain their job position and preserve the process of facilitating business affairs, employees' loyalty, enabling to be remained and achieving performance efficiency. 


\section{Macrothink}

\subsection{Statement of the Problem}

It stands out reality of phenomenon of delay in delivery of services to citizens, reviewers and routines from perspective of researchers based on thoughts of customers in order to obtain variety services, functional job methods and technical tasks done by employees of Great Irbid Municipality (GIM), which leads the capacity to absorb a long time with customers and reviewers to obtain the required services. The results will be accumulation of business affairs on citizens and wasting time and effort of employees and customers. The question of what is the impact of authority delegation on employees' performance due to efficiency, effectiveness and empowerment has been emerged.

\subsection{Objectives of the Study}

The present study aims at identifying the impact of the delegation of authority on employees' performance at great Irbid municipality. It has constructed on measuring the impact of delegation on efficiency, effectiveness and empowerment.

\subsection{Importance of the Study}

it lies on the importance of the topic related to delegation authority from high management to lower managerial levels of employees at Great Irbid Municipality. Studying such phenomenon discovers the level of centralism and decentralism applied in management of municipality affairs in which a lot of work and different services are implemented for local community and citizens due to increasing the level of service, performance and speed. This matter is going to achieve a higher level of satisfaction and loyalty to customers. Delegation authority reflects positive returns achieving efficiency, effectiveness and empowerment. In addition creating alternative leadership, trust, cooperation between functional high and medium levels or between employer and employees.

\subsection{Study Variables}

The study includes two basic and significant variables:

- Dependent Variable: Impact of delegation authority practiced and applied by high management.

- Independent Variable: Employees' performance measured by three elements (efficiency, effectiveness and empowerment).

\subsection{Study Hypothesizes}

Three hypothesizes were included:

1. There is no statically significant for the method of delegation authority on functional efficiency of employees.

2. There is no statically significant for the method of delegation authority on functional effectiveness performance of employees.

3. There is no statically significant for the method of delegation authority on functional 
empowerment of employees.

\subsection{Operational Definitions}

Delegation Authority: Waiving some administrative levels on powers and authorities for lower functional levels to help them in completing quests in order to providing services easily and rabidly for customers and benefices.

Employees' Performance: Level of efforts and achievements exerted by employees. It can be measured through following elements:

-Functional Efficiency of Employees: Employees' capability on completing quests authorized perfectly guarantee speed and accurate in addition, it saves time and efforts. Moreover, it increases level of quality in performance.

- Effectiveness Performance of Employees: Employees' capability on completing quests authorized creatively guarantee increasing in level of performance and cooperation among job levels in completing quests and adopting with conditions of different at organization.

-Functional Empowerment of Employees: Acquisition the skills and additional knowledge for employees in order to increase and raise levels of self-trust. It gives them capability to complete quests authorized and customers' services directly without asking the director.

\subsection{Methodology}

1.7.1 Study Method: Descriptive approach was applied depending on empirical method through process of data collection.

1.7.2 Study Sources (references): Two sources have been applied in data collection and they were:

- Secondary: They were collected from relevant references and depending on traditional and electronic libraries, getting benefits form contents such as textbooks, literature review (previous studies) and journals.

- Primary: A questionnaire designed for the purposes of the study in which it corresponds its variables for data collection related to employees working in Great Irbid Municipality (GIM) in northern region of Hasmite Kingdom of Jordan (HKJ).

\subsubsection{Study Population}

It was consisted of employees working in GIM in northern region of Jordan. They reached (1500) distributing on different sites of Irbid. However, the study was focused on middle and executive functional levels. Employees of lower levels have been expected.

The researchers have selected random sample reaching to 200 employees and distributing on them. (166) of questionnaire were considered retrieval and (6) weren't appropriate for data analysis. The final result was (160) forming $80 \%$ of study population. It is a high percentage 
and it allows generalizing the results (Sekaran, 2006).

Likert Scale was used for questions measurement. It was divided into (highly agree, agree, don't know, don't agree and highly don't agree).

\subsubsection{Data Collection}

The questionnaire was applied for data collection related to the questions and the objectives of the study. It was divided into two parts:

- First Part: it includes demographic features (gender, experience and qualification).

- Second Part: it includes paragraphs measuring impact of the delegation of authority on employees' performance. (1-6) measures due to effectiveness. (7-14) measures due to sufficiency. (15-21) measures due to empowerment.

\subsubsection{Reliability and validity of the questionnaire}

Researchers show questionnaire to arbitrators who have long experience in academic field and they were specialized in business administration and statistics. In the light of that, all the modification has been conducted according to paraphrasing, development to be achieved accurately and clearly.

\subsubsection{Data Analysis Method}

SPSS was used and means, standard deviations, percentages, frequencies, T-test and Cronbach Alpha equation were calculated and extracted.

\section{Theoretical framework}

Delegation of authority is a must in succeeding the operations of the management to grantee the outcomes. So, in this case high management authorizes some of its responsibility to executives in the fields of human resources. Furthermore, necessity of authority delegation has appeared due to the reasons of development in technology, its reflection to managerial developing, and business diversity of an organization. Also, it is hard to implement all tasks and whole business by employees without taking support and encouragement from high management. In this case authority delegation is considered a response for requirements of democratic system allowing to managers in all levels to participate in decision-making to perform managerial business and division of work.

Perhaps the most important point should be taken into consideration is that administrative work focuses on defining the responsibility of an employee before the employer while using authority delegation. An employer cannot evade his responsibility related to organizational activities despite of Responsibility isn't able to be authorized (AL-Shrqaui, 2002).

The right of dispose and take decisions in a specified range extent required to accomplish certain tasks. Dent has entrusted with certain administrative powers for some of aides who trust them and delegated authorities that enable them to act for the performance of these terms of reference efficiently and effectively (Hashim, 2001). 


\section{Macrothink}

International Journal of Human Resource Studies

ISSN 2162-3058

2015, Vol. 5, No. 3

It also means that the manager determines tasks that have to be implemented by one of his employees and given necessary authority to do this work. In this case employer is still responsible on decision-taking, issuing rules, instructions and regulations.

Dessler (2006) has defined it as "it is an authority transportation form high management to executives".

Lutgans \& Hodgetts (2004) said about it "it is a process of distributing tasks and authorities".

Authorization is the process in which manager is commissioned his staff to perform some work that related to his liability and perform some tasks that aren't embedded by risk effect on the institution (Fleih \& Abd AL-Majeed, 2005).

Authorization can be defined as a distribution right of dispose and make decisions in a specified range and to the extent necessary to accomplish certain tasks entrusted manager has some powers to his assistants and give them the necessary authority to perform these tasks (AL-Ali \& Mosawi, 2001).

From mentioned above, authorization is granting a part of authority for specific employee or teamwork to perform particular tasks. They also take into consideration the responsibility of implementing the work.

On the other hand, authority can be defined as acquired right in issuing commands in which job grants for the employees (ALaqi, 1996). It was also defined as the right granting to an employee enabling him for directing the others and issuing rules and obligations that must be followed (Makawi, 1995).

Authorization is a permit to perform the work and the employer has ensure that authorization includes achieving the work needed and committing mistakes because the employee is responsible to perform work and achieve it correctly and appropriate way. In this case, many managers prevent authorization for many reasons including employees distrust, knowing the way to achieve work and perform it effectively. They are seeking to satisfy managers by feeling that management desires from the to perform the work and control on all matters.

\subsection{Terms of Authorization}

1. Authorization shall be partly not total for all kinds of authority whether the multiplicity of commissioner.

2. Authorization decision shall be declared.

3. Authorization shall not be occurred with delegated authorized.

4. Authorization shall be expressed as situated by the law, if not authorization may be expressed verbally or by telephone.

5. Authorization is prohibited in the text which should not be authorization in particular competence it has been explicitly or implicitly prohibited by constitutional or legislative text (Dorah, etal, 2002). 


\section{Macrothink \\ International Journal of Human Resource Studies \\ ISSN 2162-3058 \\ 2015, Vol. 5, No. 3}

\subsection{Principles of authorization}

Many authors such as AL-Helou (2010)., Al-Sheikh, etal (2009) stated that authority involves main principles, which are:

1. Tasks and duties authorized shall be determined, particular, clear, and explicit. In addition, authorizations are able to achieve the outcomes.

2. Effectiveness of communications means between employee and employer by keeping means online among them.

3. Selecting the employee correctly. Ability and sufficient of an employee are considered the requests of effective authorization.

4. Not to criticize employees, Criticism makes subordinate resist accepting authorization for additional work. If error has occurred, the imbalance should be explained in the same way that improves performance in long-run outcomes.

5. Granting an employee sufficient power and authority to perform these duties, as well as giving him the right to make decisions and issue instructions to carry out the duties and tasks.

6. Be aware from transforming work between employee and employer.

\subsection{Types of authorization}

There are different types for the authority such as (Aboqahv, 2003):

- Delegated Authorization: it means transmitting the power from high authority to low authority. In addition, disgorged powers from among the elements of authorization. Either the party or the authorized person to exercise powers delegated to the other throughout the duration of the authorization gives the center Position of the higher authority to the lowest power regardless of the incumbent or the supreme authority or minimum.

- Signature authorization: it is commissioned by the authority of the supreme authority lower than the signing of some business or administrative decisions on its behalf. Delegation of signature does not mean giving up the powers.

\subsection{Elements of Authorization}

- Tasks and duties: the manager authorizes a person or a group particular duties and tasks. These ask may be as image of an activity in which an individual assigned or objectives have to be achieved by employees. These tasks are established by the manager in order to authorize the work perfectly.

- Authority: the legal right in issuing commands to be achieved and carried out by employees.

- Responsibility: Vowing and commitment of the employee to carry out specific tasks and duties. 
- Efficacy: capability to use sources to achieve particular objective (Longenecker and Pringle, 1984).

This means if the manager owned power, he could give a part of his powers to one of the workers to perform the functions and duties that are part of its terms of reference to be completed and when the Commissioner has therefore accepted it becomes responsible for undertaken and accomplished. Adding to that, Commissioner remains responsible in before superiors. When the manager authorizes one of the workers, he must interest in capability of employee to perform the work and ensure if he desires or not.

\subsection{Advantages of Authorization}

- Authorization achieves significant return of the organization with little cost. It saves time in all management levels, achieves speed in performing managerial work, managerial flexibility, adopting with different conditions and develop entrepreneurship of the employees. It also brings new idea and creates wider area of thinking where the more than one level takes place in achieving business collectively. So, the outcomes will be improved.

- Preparing future leaders to motivate the employees authorized on objective reasoning, compering and showing results and outcomes. It allows selecting future managers by conducting appropriate level test for a job vacancy.

- Equity and social justice where authorization one of factors of achieving social justice in which power becomes an element of democracy (Al-Sheikh, etal, 2009).

\section{Literature Review}

Hashem et. al, (2013) conducted study on the impact of structural empowerment in achieving psychological empowerment. The study has reached that there is a statistical significant between availability of structural empowerment representing by delegation authority, Personality development, participation and Development innovative behavior on achieving psychological empowerment representing by one's awareness that he holds an important and meaningful job position, feeling effective, independence and capability to be effective.

AL-Matouh (2003) studied the role of delegation of authority in achieving the objectives of organizing. The study has reached that delegation of authority has played a basic role in achieving business fast. It raises the morale among workers. It allows the chance for building employees and enables them to alternative leadership and ability to manage organizations.

While the study of AL-Qaryouti (2006) on the feeling job empowerment among managers of middle management level in Kuwait. The study depended on a random sample reached to (445) employees represent managers of middle management and they work in public institutions in Kuwait. The study has reached for different results as following: there are important factors enhancing feeling in job empowerment, and they differ due to demographic features of samples participants. 


\section{Mll Macrothink}

International Journal of Human Resource Studies

ISSN 2162-3058

2015, Vol. 5, No. 3

The study of Schriesheim, etal (2008) on the delegation and leadership- member exchange: main effects moderators measurement issues. Subordinate and supervisor leader-member exchange (LMX) were examined as correlates of delegation and as moderators of relationships between delegation and subordinate performance and satisfaction. Raw score analyses of data on 106 dyads showed both to be significantly related to delegation and to have similar main and moderating effects for subordinate performance and satisfaction. Finally, within- and between-groups analyses largely supported the level-of-analysis predictions of the LMX approach. Implications for future LMX research are discussed.

Wadi (2009) conducted study on the impact of authority delegation on managerial performance. The study aimed at identifying the impact of authority delegation on workers performance of Sudan University of Science \& Technology (SUST). Sample of the study was consisted of (60) workers and they were randomly selected. The study have reached for following results: delegation of authority strengthens human relations among members of the organization, enhance self-confidence among workers and increase the level of achievement in tasks and work assigned for workers and speed of implementation.

The study of AL-joqi (2010) on the impact of delegation of authority on the effectiveness of management decisions. The results of study have shown that the level of applying authority delegation in yamen Oil Company was low. Also, there is a strong and positive relation between successes of delegation process and heads' sufficiency. The company has sought for achieving its objectives in the light of taking effective decisions. In addition, if the company doesn't apply authority delegation among employees, this will depress them and there is no motivation in implementing managerial decisions. So, high managements decisions will not be effected and have important value.

But the study of Senyuta (2013) titled delegation and performance. This paper empirically investigates how the level of authority delegation is related to the performance of an organization. Decentralized, horizontal organizational structure takes advantage of more efficient decision making, mainly due to more efficient use of "soft" information. The cost of such decentralization is the loss of control and the need to properly incentivize agents who are legitimately given the authority to make decisions. This is the trade-off organization faces when deciding on the level of authority delegation.

The study of Shekari, et al (2011) on the relationship between delegation authority process and rate of effectiveness: case study municipality regions of Mashhad. Findings of this study suggested that in general, between the delegation authority process and rate of effectiveness there is a significant correlation ( $\mathrm{P}$-value $=0.000)$, also, between delegation authority process, including: preparation, appreciation stage and effectiveness, there is a significant relationship. The greatest effect among five stage of delegation authority process, the aspects of appreciation and preparation is related to, So that the power of explains appreciation equal to 0.165 and the power of explains preparation equal to 0.142 is.

The study of Fehr, etal (2011) on the lure of authority: motivation an Authority and power. The study studied the motivation and incentive effects of authority experimentally in an authority-delegation game. Individuals often retain authority even when its delegation is in 
their material interest suggesting that authority has nonpecuniary consequences for utility. Authority also leads to overprovision of effort by the controlling parties, while a large percentage of subordinates underprovide effort despite pecuniary incentives to the contrary. Authority thus has important motivational consequences that exacerbate the inefficiencies arising from suboptimal delegation choices' incentive effects of power".

Awawdeh (2014) conducted study on the regulatory factors affecting the administrative authority: the perceptions of staff (managers) in Jordanian ministries centers. The study found that there were no statistically significant differences at $(\alpha \leq 0.05)$ in perceptions about the administrative authority attributed personal and functional for the following variables (gender, age, years of experience), while there is statistically significant at $(\alpha \leq 0.05)$ for perceptions of staff of the factors affecting the administrative authority in the ministries centers Jordan attributed to the educational qualification variable and vary with it for the rest of demographic factors. The study recommended the importance of diagnosis Regulatory barriers that may limit the dissemination of culture and policy mandate and on two levels: the first regards as element manager's Influential industry in this culture and its pro source or vice versa, and the second related to staff delegation and awareness of their culture and environment.

The study of Darwish (2010) on the delegation of authority to the best method to raise the efficiency of job performance. The research aims to diagnose the actual reality of the exercise of the powers delegated by the organization research sample and its impact on the performance efficiency and identifying the concept of delegation of authority as an act of administrative and positive role functionality in the efficiency of organizations in general, and in particular, the organization surveyed among the most important results of the research is to follow the tide of revelation inaccurate for people and committees that have been delegated authority resulting in some of the directions that do not serve the administrative work in the surveyed Organization, and the method adopted version in organizational units is weak, due to the weakness of directors informed of the latest developments that rate methods modern administrative work.

AL-Qaryoni (2003) studied the trends for those who occupy leading jobs in ministries and public departments in Kuwait for authority delegation. The study has discussed the rends for those who occupy leading jobs in ministries and public departments in Kuwait for authority delegation due to the definition, importance, extent of relaxation or feeling that it is a threat for their leading roles. The study has recommended in following suggestions:

- The need to take into account different official sides to select leading functions at ministries and official departments.

- The need to conduct training courses for the present leaders as conferences and workshops and define disadvantages of centerlisim and authority monopoly by managers

- The need to provide material and moral incentive employees to accept the authorization, and that by linking efficiency in the exercise of powers delegated to 
them material and moral incentives.

The study of Frehiat \& Alawneh (2000) on the factors effect on authority delegation in industry: an empirical study. The study aimed at identifying the factors effect on authority delegation in industry. Many models have been established to interpret some actions and perceptions relating to delegation. The study reached for following results: most perspectives of managers were positive. Practice delegation associated with conviction of the importance of the delegation of authority manager level information exchange mechanisms available in the institution. In addition delegation isn't related to appropriate time for taking decisions by manager, controlling, employees' experience and raising their productivity. The models of have shown that the source of the factors are psychological, mental and personal related to manager more than to these relate to the institution and economic and legal information.

The study of AL-Adaila (1998) on the delegation of authority in Jordanian public institutions: an empirical study. The study aimed at identifying level and degree of delegation of managerial authority in public institutions. The results of the study have shown that the degree of applying delegation was medium. Also, there is a statistical significant for variable of method of taking decisions and trust degree among elements of delegation process and speed in finalizing transections. In addition, there is a statistical significant for variables of (age, job position and experience). Whereas, there is no statistical significant for variable of qualification.

The study of Awamleh (1994) under the title of delegation of authority in public and private institutions: an empirical study. The study aimed at analyzing definition of delegation of authority through a selected sample has been taken from institution of both sectors (public and private). The study has reached for following results:

- There is a huge gap between self - convocation in delegation of authority and extent of applying by researchers.

- Similarity in delegation authority motivations in public and private institutions.

- Difference in methods authority delegation inside both sectors.

- Similarity of general trend about the features employees to whom authority delegated.

- There were significant obstacles for delegation of authority in both sectors including weakness in trust, lack of training, rigidity of legislations and retardation of organizational structures.

The study recommended in necessity narrowing the gap between conviction and authorization applied. Necessity of adopting clear basics for authorization and identifying its different sides in order to conduct more empirical studies. 


\section{Al Macrothink \\ International Journal of Human Resource Studies \\ ISSN 2162-3058 2015, Vol. 5, No. 3}

\section{Data Analysis}

\subsection{Tool Validity}

It was selected due to test Cronbach Alpha equation, table (1) shows the following:

1. Alpha value of performance efficiency dimension reached to (0.70).

2. Alpha value of employees' satisfaction dimension reached to (0.82).

3. Alpha value of advantages of delegation at organization dimension reached to (0.77).

4. Total was $(0.82)$.

All these values are more than $(0.60)$. So, tool is valid

Table (1): Cronbach Alpha test results

\begin{tabular}{|l|l|}
\hline Field & Alpha \\
\hline performance efficiency & 0.70 \\
\hline Performance effectiveness & 0.82 \\
\hline Employees' empowerment & 0.77 \\
\hline Total & 0.82 \\
\hline
\end{tabular}

\subsection{Demographic features descriptions:}

Table (2) shows the following:

Gender: $57.61 \%$ was males and others females

Qualification: $55.43 \%$ of sample's individuals have got bachelor, $19.02 \%$ diploma, $13.04 \%$ secondary. $12.50 \%$ have got higher studies.

Experience years: $\quad 48.37 \%$ was from category of (10- less than 15 years). $28.26 \%$ for those experiences are less than 5 years. $23.37 \%$ for those experiences equal or more 10 years. 


\section{Macrothink \\ International Journal of Human Resource Studies \\ ISSN 2162-3058 2015, Vol. 5, No. 3}

Table (2): frequencies and percentages for demographic features

\begin{tabular}{|l|l|l|l|}
\hline Variable & Category & Frequencies & Percentages (\%) \\
\hline \multirow{2}{*}{ Gender } & Males & 106 & 57.61 \\
\cline { 2 - 4 } & Females & 78 & 42.39 \\
\hline \multirow{3}{*}{ Qualification } & Secondary & 24 & 13.04 \\
\cline { 2 - 4 } & Diploma & 35 & 19.02 \\
\cline { 2 - 4 } & Bachelor & 102 & 55.43 \\
\cline { 2 - 5 } Years & Higher studies & 23 & 12.50 \\
\hline \multirow{2}{*}{\begin{tabular}{l} 
of \\
\cline { 2 - 4 }
\end{tabular}} & Less than 5 years & 52 & 28.26 \\
\cline { 2 - 4 } & 5-less than 10 years & 89 & 48.37 \\
\cline { 2 - 4 } & More than 10 years & 43 & 23.37 \\
\hline
\end{tabular}

\subsection{Test of hypothesizes}

4.3.1 Hypothesis (1): There is no statistical significant for delegation of managerial authority on job performance efficiency.

Table (3) shows that all paragraphs' means were more than 3.00 at $(\alpha \leq 0.05)$. Paragraph (1) ranked first with (3.91) mean. It measures that delegation develops positive relations among employees. Next, paragraph (5) (3.9) and then paragraphs $(3,4,6)$ respectively. Paragraph (2) measuring capability of delegation to upgrade level of employee's performance ranked final. The total mean for all paragraphs was (3.85) at $(\alpha \leq 0.05)$. It was statistically significant. First hypothesis was refused.

So, there is a statically significant for authority delegation on developing employees' performance at Great Irbid Municipality (GIM). 


\section{Macrothink}

International Journal of Human Resource Studies

ISSN 2162-3058

2015, Vol. 5, No. 3

Table (3): means, standard deviation, $T$ and $\alpha$ for field of employees' performance efficiency

\begin{tabular}{|c|c|c|c|c|c|}
\hline No. & Paragraph & Mean & Std. deviation & $\mathbf{T}$ & $\alpha$ \\
\hline 1 & $\begin{array}{l}\text { Delegation increases level of } \\
\text { positive relations among different } \\
\text { jobs. }\end{array}$ & 3.91 & 1.01 & 7.00 & 0.00 \\
\hline 2 & $\begin{array}{l}\text { Delegation upgrades level of job } \\
\text { performance. }\end{array}$ & 3.79 & 1.42 & 1.82 & 0.08 \\
\hline 3 & $\begin{array}{l}\text { Authorization invests the time } \\
\text { ideally in achievement process of } \\
\text { organization. }\end{array}$ & 3.85 & 1.13 & 2.9 & 0.01 \\
\hline 4 & $\begin{array}{l}\text { Authorization instills loyalty and } \\
\text { belonging to the Organization. }\end{array}$ & 3.83 & 1.29 & 1.92 & 0.02 \\
\hline 5 & $\begin{array}{l}\text { Delegation accelerates decision } \\
\text { making process. }\end{array}$ & 3.90 & 1.48 & 3.21 & 0.00 \\
\hline 6 & $\begin{array}{l}\text { Delegation creates principle of } \\
\text { entrepreneurship in employee's } \\
\text { performance. }\end{array}$ & 3.80 & 1.1 & 1.99 & 0.02 \\
\hline \multicolumn{2}{|c|}{$\begin{array}{l}\text { The impact of managerial delegation on } \\
\text { employees' performance efficiency. }\end{array}$} & 3.85 & 0.91 & 7.28 & 0.00 \\
\hline
\end{tabular}

4.3.2 Hypothesis (2): there is no statistical significant for managerial authority delegation on employees' performance effectiveness.

Table (4) shows that all paragraphs' means were more than 3.00 at $(\alpha \leq 0.05)$. Paragraph (7) ranked first with (4.03) mean. It measures extent of employees accepting overtime. Next, paragraph (9) (4.02) and then paragraphs $(14,12,8,13,10)$ respectively. Paragraph (11) measuring extent of delegation improves the perspective from employer to employee ranked final. The total mean for all paragraphs was (3.96) at $(\alpha \leq 0.05)$. It was statistically significant. Second hypothesis was refused .

So, there is a statically significant for authority delegation on employees' satisfaction at Great Irbid Municipality (GIM). 


\section{Macrothink}

International Journal of Human Resource Studies

ISSN 2162-3058

2015, Vol. 5, No. 3

Table (4): means, standard deviation, $T$ and $\alpha$ for field of employees' performance effectiveness

\begin{tabular}{|c|c|c|c|c|c|}
\hline No. & Paragraph & Mean & Std. deviation & $\mathbf{T}$ & $\alpha$ \\
\hline 7 & $\begin{array}{l}\text { Delegation makes me accept } \\
\text { overtime positively. }\end{array}$ & 4.03 & 0.86 & 10.00 & 0.00 \\
\hline 8 & $\begin{array}{l}\text { Delegation raises amount of work } \\
\text { achieved. }\end{array}$ & 3.95 & 1035 & 4.47 & 0.00 \\
\hline 9 & $\begin{array}{l}\text { Delegation gives me a chance to } \\
\text { adopt with different conditions at } \\
\text { organization. }\end{array}$ & 4.02 & 0.94 & 9.18 & 0.00 \\
\hline 10 & $\begin{array}{l}\text { Delegation makes me aware all the } \\
\text { time of work. }\end{array}$ & 3.89 & 1.18 & 3.79 & 0.00 \\
\hline 11 & $\begin{array}{l}\text { Delegation improves the perspective } \\
\text { from employer to employee. }\end{array}$ & 3.88 & 1.26 & 3.03 & 0.00 \\
\hline 12 & $\begin{array}{l}\text { Delegation helps me to achieve my } \\
\text { work in limited time. }\end{array}$ & 3.97 & 1.14 & 5.46 & 0.00 \\
\hline 13 & $\begin{array}{l}\text { Delegation gives me a chance to } \\
\text { depend on myself in achieving work. }\end{array}$ & 3.91 & 1.33 & 5.20 & 0.00 \\
\hline 14 & $\begin{array}{l}\text { Delegation increases degree of effort } \\
\text { and interest in achieving the } \\
\text { objectives at the organization. }\end{array}$ & 4.00 & 0.70 & 9.80 & 0.00 \\
\hline \multicolumn{2}{|c|}{$\begin{array}{l}\text { The impact of managerial authority } \\
\text { delegation on employees' performance } \\
\text { effectiveness }\end{array}$} & 3.96 & 0.83 & 13.22 & 0.00 \\
\hline
\end{tabular}

4.3.3 Hypothesis (3): there is no statically significant for managerial authority delegation on employee's performance empowerment.

Table (5) shows that all paragraphs' means were more than 3.00 at $(\alpha \leq 0.05)$. Paragraph (21) ranked first with (3.99) mean. It measures extent of delegation eliminates the central authority in decision-making. Next, paragraph (19) (3.96) and then paragraphs $(20,16,18,17)$ respectively. Paragraph (15) measuring extent of delegation contributes not to business 
disabled because of the absence of the administrative leader ranked final. The total mean for all paragraphs was (3.93) at $(\alpha \leq 0.05)$. It was statistically significant. Second hypothesis was refused.

So, there is a statically significant for authority delegation on achieving advantages for organization and employees at Great Irbid Municipality (GIM).

Table (5): means, standard deviation, $T$ and $\alpha$ for field of authority delegation on achieving advantages for organization and employees

\begin{tabular}{|c|c|c|c|c|c|}
\hline No. & Paragraph & Mean & $\begin{array}{l}\text { Std. } \\
\text { deviatio } \\
\text { n }\end{array}$ & $\mathbf{T}$ & $\alpha$ \\
\hline 15 & $\begin{array}{l}\text { Delegation prevents work displaying in } \\
\text { the case of manager absence. }\end{array}$ & 3.85 & 1.30 & 2.18 & 0.00 \\
\hline 16 & $\begin{array}{l}\text { Delegation increases principality and } \\
\text { initiative to prove oneself and excellence } \\
\text { in performance }\end{array}$ & 3.92 & 1.14 & 5.83 & 0.00 \\
\hline 17 & $\begin{array}{l}\text { Delegation strengthens self-confidence of } \\
\text { subordinate's level. }\end{array}$ & 3.89 & 1.30 & 2.84 & 0.00 \\
\hline 18 & $\begin{array}{l}\text { Delegation increases degree of satisfaction } \\
\text { on job needs. }\end{array}$ & 3.91 & 1.34 & 3.82 & 0.00 \\
\hline 19 & $\begin{array}{l}\text { Delegation leads to building institutional } \\
\text { work within the organization }\end{array}$ & 3.96 & 1.22 & 6.48 & 0.00 \\
\hline 20 & $\begin{array}{l}\text { Delegation leads to offer opportunities of } \\
\text { discover creative and effective managerial } \\
\text { leads }\end{array}$ & 3.95 & 1.19 & 4.37 & 0.00 \\
\hline 21 & $\begin{array}{l}\text { Delegation reduces the level of centerlisim } \\
\text { in decision-taking }\end{array}$ & 3.99 & 0.95 & 70.07 & 0.00 \\
\hline \multicolumn{2}{|c|}{$\begin{array}{l}\text { The impact of managerial authority delegation } \\
\text { on employee's performance empowerment. }\end{array}$} & 3.93 & 1.02 & 6.72 & 0.00 \\
\hline
\end{tabular}




\section{Macrothink}

\section{Results of the Study}

The most important results of the study are:

1. There is a statically significant for authority delegation on developing employees' performance at Great Irbid Municipality (GIM). Delegation develops positive relations among employees were in in the first rank. Capability of delegation to upgrade level of employee's performance ranked final.

2. There is a statically significant for authority delegation on developing employees' performance efficiency at Great Irbid Municipality (GIM). Extent of employees accepting overtime was in first ranked. Extent of delegation improves the perspective from employer to employee ranked final.

3. There is a statically significant for authority delegation on employees' empowerment at Great Irbid Municipality (GIM). Extent of delegation eliminates the central authority in decision-making extent of delegation contributes not to business disabled because of the absence of the administrative leader ranked final.

\section{Recommendations}

The researchers recommend the following:

1. The study recommends (GIM) to progress the process of activating managerial authority delegation for employees and increasing the level of delegation confirms with the amount of tasks in order to upgrade job performance.

2. The necessity for studying the mechanism and improving managerial authority delegation to be reflected on increasing employees' satisfaction level in all fields. Also, to improve the impression the subordinates for heads.

3. GIM has to increase level of employees empowerment to able to implement tasks individually without referring to high management for saving time and effort and offering services for customers, being ready for planning and strategies related to long run objectives of the organization.

4. Conducting more studies about different elements of managerial authority and be implementing on other public and private institutions.

\section{References}

Aboqahv, Abdul Salam (2003). Manager in delegation of authority Guide, New University Publishing House - Alexandria - Egypt.

Alaqa Bdakadir (1996). Administration analytical study of the functions and administrative decisions - T1- Jeddah.

Alazailh, Muhammad Ali (1998). delegation of authority in the Jordanian public institutions Empirical Study - the scientific journal of the Faculty of Economics, University of Qatar Number 9. 
AL-Helou , Mohammed Abdul-Aziz (2010). The impact of devolution of powers to the managerial skills of employee's development, Master Thesis.

Ali, Reza., and the Moussawi, Sinan (2001). Functions contemporary management panoramic overview-Amman, Warraq Foundation Publishing.

AL-Matouaa, Ahmed (2003). The role of delegation of authority in achieve the objectives of the organization, Naïf Arab University for Security Sciences, Master Thesis unpublished.

Awamleh, Nael Abdel-Hafiz (1994). Empirical Study of the concept of delegation of authority in the Jordanian public and private institutions - the Journal of King Abdul Aziz University - Economics and Management.

Awawdeh, Atef (2014). Factors affecting the administrative authority, the perceptions of staff (managers) in the Jordanian ministries centers, administrative science studies, issue 41.

Certo , Samuel (1995). Modern Management Quality- Ethics and the Global Environment, Fifth Edition, Rollins colleges.

Darwish, al-Shammari., And Maher Sabry Ibrahim Rashid (2010). Delegation of authority to the best method to raise the efficiency of job performance - a study of the views of a sample of managers in the General Company for the manufacture of fertilizer - Central Region Kufa - Iraq - Journal of Management and Economics, Issue 82.

Dessler, Gary (2006). Management principles and practices for tomorrow's leaders, Florida International University, Person, Prentice Hall.

Deub, Ayman Hassan (2014). Empowerment employees as an input to improve the quality of career in the telecommunications sector (Empirical Study), Damascus University economic and legal for Science journal, 30 folder, the first issue, p: 195-224.

Dorah, Abed bari., Madhon Mosa and Jazrawi Ebrahem (2002). Contemporary Management, concepts and procedures, $2^{\text {nd }}$ part, student's Arab center services, Amman, Jordan.

Fehr,Ernst,Herz,Holger and wilkening, Tom (2013). The Lure of authority: motivation and incentive effects of power, American economic review, 103, 4, pp.1325-1359.

fillet, Farooq, Abdul Majid (2005). Organizational Behavior in the management of educational institutions, Oman, Dar march for publication.

Freihat, Haidar., And Alawneh Ali (2000). Factors of delegation of authority in the Jordanian industrial sector, a field study - 5 - issue 1.

Fuad Al-Sheikh Salem; Makhamreh, Mohsen; Al-Dahan, Omaima \& Ramadan, Ziyad (2009). Modern Management Concepts, 9th Edition, Jordan Books Cneter, Amman.

Hashem, Zaki Mahmoud 2001). Management basics, Kuwait, AL-Salasl.

Hashem, Zaki Mahmoud (1988). Regulation and ways of working, Kuwait, AL-Salasl.

Hashim, Tariq; A Ahmed, and Jaradat Nasser (2013). The impact of structural empowerment 
in achieving psychological empowerment in the Jordanian public organizations, Journal of Hebron University for research, folder 8, Number 1.

Jawqa, Adnan Mohammed (2010). The impact of delegation of authority in the effectiveness of managerial decisions: An Empirical Study on the Yemeni oil company in the capital Sanaa, unpublished Master Thesis, School of Finance and Banking, Sanaa, Yemen.

Longenecker, Justin and Pringle, Charles (1984). Management, $6^{\text {th }}$ edition, Charles E. Merrill Publishing Company, Columbus, USA.

Lutgans, fred \& Hodegtts, Richard (2004). Business, second edition, McGraw, hill Book Company.

Makawi, Atef Mustafa (1995). Authority and responsibility in the management of social institutions, Alexandria, third Conference of the Islamic guidance for social service.

Qaryouti, Mohammad Qasim (2006). A sense empowerment among managers of middle management level in Kuwait, Damascus University Journal of economic and legal sciences, 22 folder, number 1, pp. 281-310.

Qaryouti, Mohammad Qasim Ahmad (2003) - Trends the occupant's leadership positions in the ministries and government departments in the State of Kuwait to authorize the issuance folder 43. 2 .

Schriesheim,Chester A,etal ( 2008). Delegation and leadership-member exchange: main effects, moderators, measurement issues, Academy of management Journal, 41, (3), p p.229-318.

Sekaran, Uma, (2006). Research Methods for Mangers: A Skill-Building Approach, New York: John Willey and Sons.

Senyuta, Olena (2013). Delegation and Performance, Charles University, center for economic research and graduate education, Academy of sciences, Zech republic, and economic institute.

Serafi, Mohamed Abdel Fattah (2003). Leading management, Safa House for Publishing and Distribution, Amman, Jordan.

Sharkawy, Ali (2002). Management process, the functions of managers, Alexandria -Dar AL-Jaded University for Publishing and Distribution.

Shekari,Gholamabba., Naieh, Moshizadeh and Nouri. Reza Seid (2011). Relationship between delegation authority process and rate of effectiveness (case study municipality regions of mash had), Interdisciplinary Journal of contemporary research in Business, Vol.4 No.5, pp.870-889.

Wadi, Khamis Adam (2009). The impact of delegation of authority to managerial performance, unpublished Master Thesis, University of Sudan for Science and Technology, Faculty of Business Studies, Sudan. 


\section{Macrothink}

\section{Questionnaire}

Dear employees at Great Irbid municipality,

After all greetings,

This is a questionnaire of authority delegation: an empirical study. Please, we hope to be filled with interest for reaching scientific objectives. This information will be dealt confidently for the purposes of scientific research.

Thank you for your cooperation and responses

\section{First: Demographic Features}

- Gender: $\square$ Male $\quad \square$ female

- Experience: $\square$ Less than 5 year's $\square$ 5- less than 10 years $\square$ More than 10 years.

- Qualification: $\square$ Secondary $\quad \square$ Bachelor $\quad \square$ Higher Studies

Second: Following paragraphs of the questionnaire measure the question related to managerial authority delegation in employees' performance. Please put (x) on the appropriate place.

\begin{tabular}{|l|l|l|l|l|l|l|}
\hline No. & Paragraph & $\begin{array}{l}\text { Highly } \\
\text { agree }\end{array}$ & Agree & $\begin{array}{l}\text { Don't } \\
\text { know }\end{array}$ & $\begin{array}{l}\text { Don't } \\
\text { agree }\end{array}$ & $\begin{array}{l}\text { Highly } \\
\text { don't } \\
\text { agree }\end{array}$ \\
\hline
\end{tabular}

Job Performance efficiency of employees.

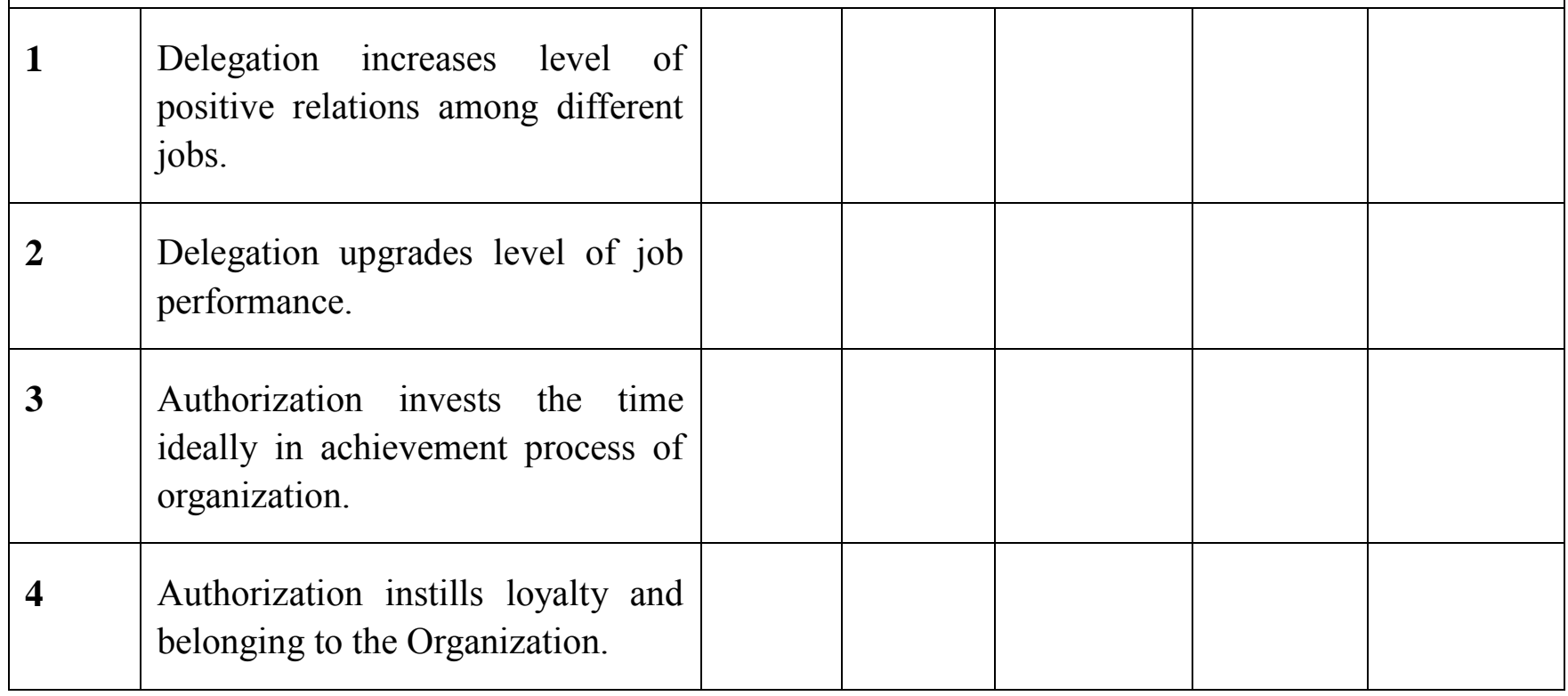




\begin{tabular}{|l|l|l|l|l|l|}
\hline $\mathbf{5}$ & $\begin{array}{l}\text { Delegation accelerates decision } \\
\text { making process. }\end{array}$ & & & & \\
\hline $\mathbf{6}$ & $\begin{array}{l}\text { Delegation create principle of } \\
\text { entrepreneurship in employees } \\
\text { performance. }\end{array}$ & & & & \\
\hline
\end{tabular}

\section{Job performance effectiveness of employees}

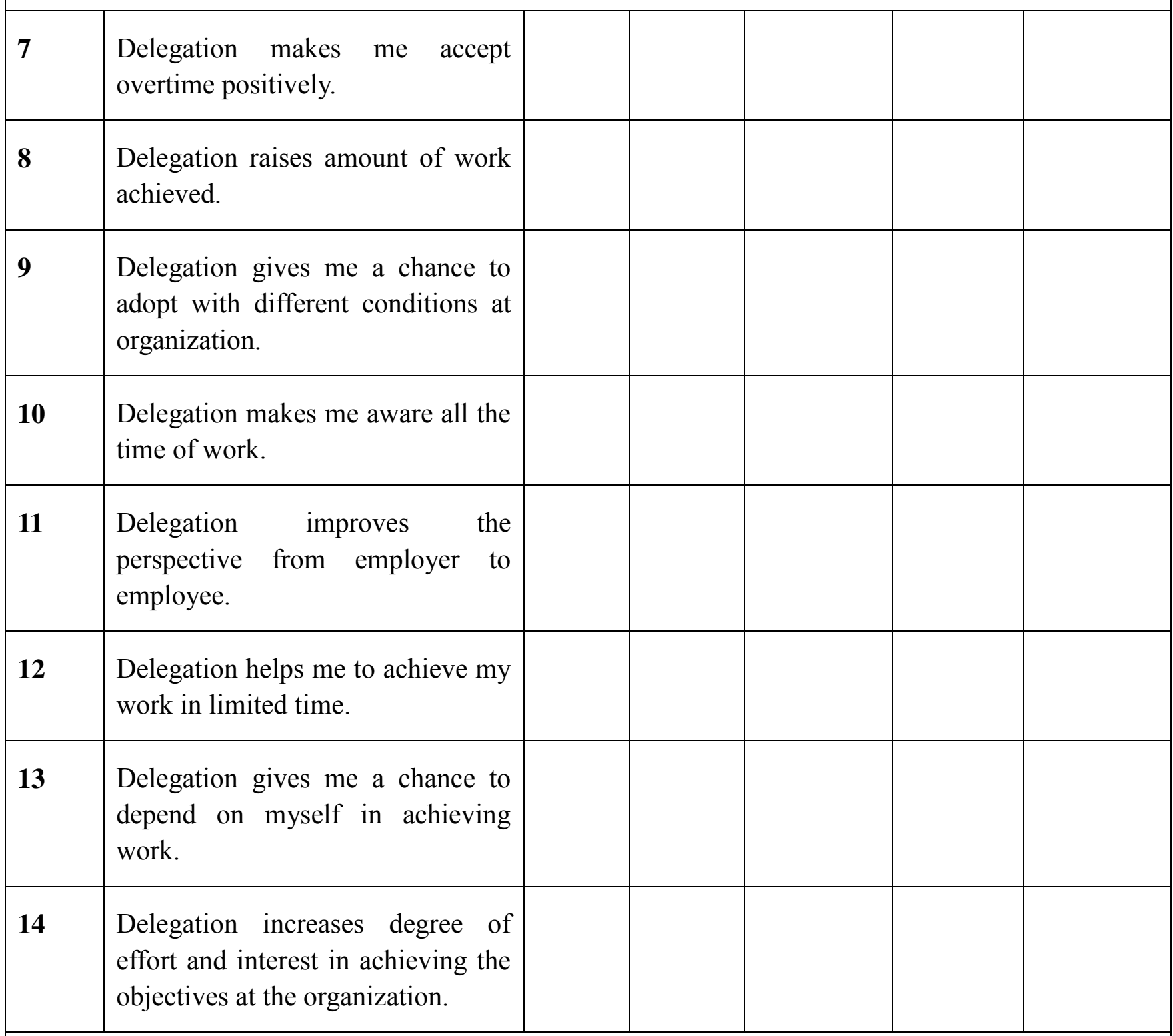

\section{Job empowerment of employees}

$15 \begin{aligned} & \text { Delegation prevents work } \\ & \text { displaying in the case of manager } \\ & \text { absence. }\end{aligned}$




\section{1) Macrothink}

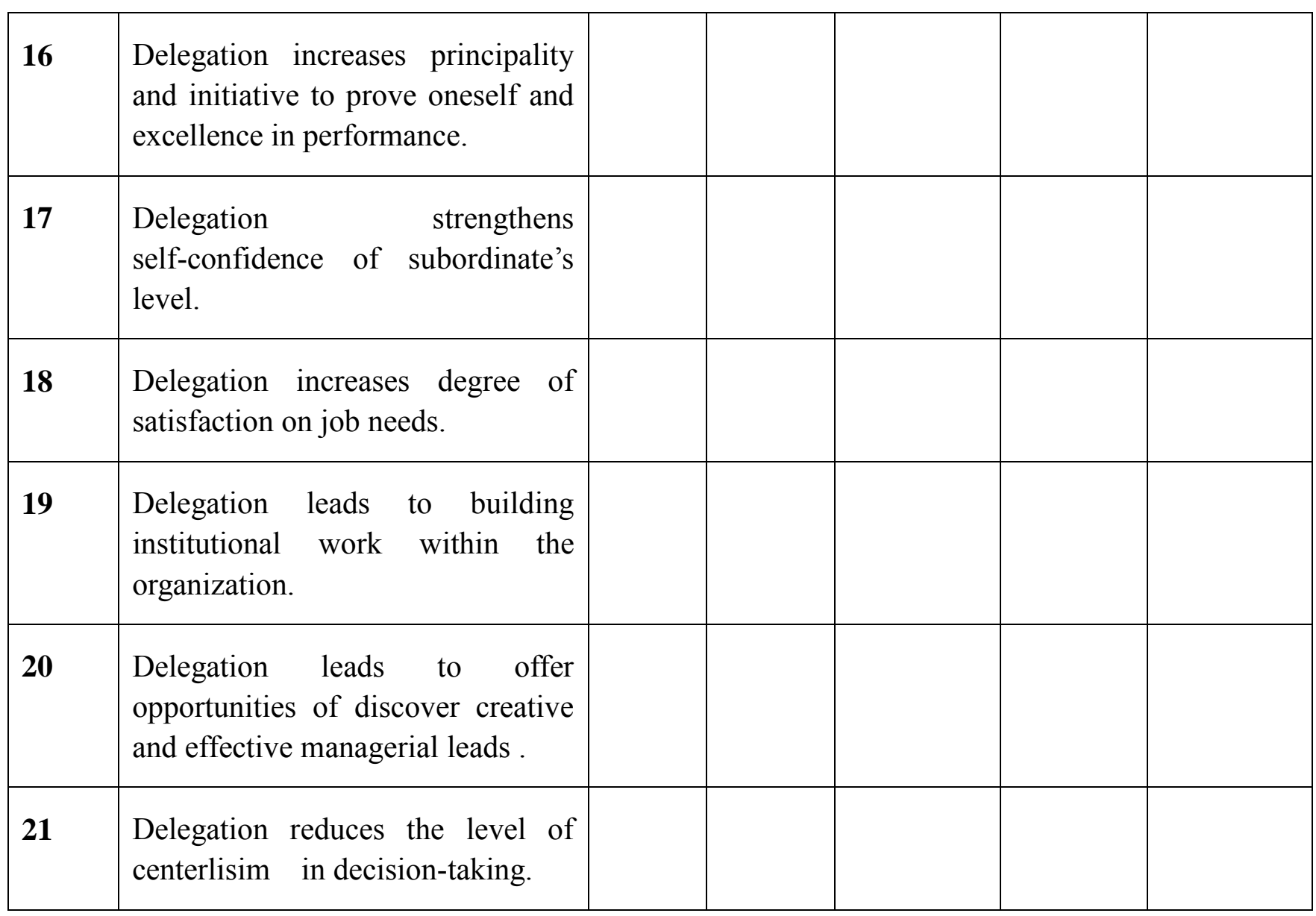

